\title{
Environmental policy and the economic downturn
}

\author{
Alex Bowen and Nicholas Stern \\ January 2010
}

Centre for Climate Change Economics and Policy

Working Paper No. 18

Grantham Research Institute on Climate Change and the Environment

Working Paper No. 16 
The Centre for Climate Change Economics and Policy (CCCEP) was established by the University of Leeds and the London School of Economics and Political Science in 2008 to advance public and private action on climate change through innovative, rigorous research. The Centre is funded by the UK Economic and Social Research Council and has five interlinked research programmes:

1. Developing climate science and economics

2. Climate change governance for a new global deal

3. Adaptation to climate change and human development

4. Governments, markets and climate change mitigation

5. The Munich Re Programme - Evaluating the economics of climate risks and opportunities in the insurance sector

More information about the Centre for Climate Change Economics and Policy can be found at: http://www.cccep.ac.uk.

The Grantham Research Institute on Climate Change and the Environment was established by the London School of Economics and Political Science in 2008 to bring together international expertise on economics, finance, geography, the environment, international development and political economy to create a world-leading centre for policyrelevant research and training in climate change and the environment. The Institute is funded by the Grantham Foundation for the Protection of the Environment, and has five research programmes:

1. Use of climate science in decision-making

2. Mitigation of climate change (including the roles of carbon markets and low-carbon technologies)

3. Impacts of, and adaptation to, climate change, and its effects on development

4. Governance of climate change

5. Management of forests and ecosystems

More information about the Grantham Research Institute on Climate Change and the Environment can be found at: http://www.Ise.ac.uk/grantham.

This working paper is intended to stimulate discussion within the research community and among users of research, and its content may have been submitted for publication in academic journals. It has been reviewed by at least one internal referee before publication. The views expressed in this paper represent those of the author(s) and do not necessarily represent those of the host institutions or funders. 


\title{
ENVIRONMENTAL POLICY AND THE ECONOMIC DOWNTURN
}

\author{
Alex Bowen and Nicholas Stern ${ }^{1}$
}

\begin{abstract}
This paper considers how environmental policies should respond to macroeconomic downturns. It first explores the implications of the global economic downturn of 2008-09 for environmental policies, focusing in particular on the example of action against climate change. The arguments for and against activist fiscal policies in general are then reviewed, and the case made that a demand-induced downturn provides a very good opportunity to undertake a necessary step change in the public spending component of environmental policies and to start working through a backlog of public investment to improve the environment. Fiscal policy should be used to improve the allocation of resources across time and space. Recent fiscal stimuli are considered in the light of this discussion. It is also argued that there is little cause to delay the introduction of price signals to internalise environmental externalities. But the levels at which such signals should be set requires careful analysis; changes over the business cycle may be warranted, depending on the nature of the environmental externality and the cause(s) of the business cycle in question.
\end{abstract}

KEY WORDS: environmental policies, pricing environmental externalities, business cycles, fiscal policies, climate change.

JEL CLASSIFICATION: E62, E65, H23, H54, Q54, Q58

\section{INTRODUCTION}

Environmental degradation threatens the quality of life and the potential for sustainable development in societies across the world. Biodiversity is suffering. Water supplies and other environmental services to mankind are coming under stress. Ocean acidification is now a problem. The OECD's latest annual Environmental Outlook 'traffic light' assessment signalled a red light for species loss, invasive alien species, loss of tropical forests, water scarcity and pollution, urban air quality and hazardous waste management (OECD, 2008). Looming over current environmental challenges is the enormous danger of human-induced climate change, which threatens to magnify existing environmental problems and ultimately transform the physical and social geography of the planet. As prospective climate change is a function of the stock of greenhouse gases (GHGs) in the atmosphere, action on this front in particular is urgent, as GHGs are continuing to accumulate in the atmosphere - and, until very recently, at an increasing rate.

These increasing pressures on the environment from population and economic growth have so far out-paced environmental policies (OECD, 2008). Environmental objectives and the sustainability of development have attracted increasing attention in development strategies, and are central to the Millennium Development Goals (MDGs) adopted by the United Nations in 2001. ${ }^{2}$ If the MDGs were being drawn up now, there is little doubt that more attention

\footnotetext{
${ }^{1}$ Grantham Research Institute on Climate Change and the Environment. We are grateful for comments from referees and editors of the Review and research assistance by James Rydge. The usual disclaimer applies. ${ }^{2}$ In particular, Goal 7 of the Millennium Development Goals is to 'ensure environmental sustainability' and embraces four targets: (1) Integrating the principles of sustainable development into country policies and
} 
would be given to environmental concerns, particularly the need to adapt to the climatechange impacts that are likely even in the event of strong international efforts to curb greenhouse gas emissions. Yet the United Nations Environment Programme concludes: "serious and persistent barriers to sustainable development remain [...] Environmental degradation is therefore undermining development and threatens development progress" (UNEP, 2009a). The United Nations' regular monitoring of progress towards the MDGs suggests that it will be very difficult to hit several of the environmental targets (UN, 2008).

Stronger environmental policies, including fiscal measures, are required on several fronts to tackle these problems. Well-designed tax and spending measures applied over the long term can improve the allocation of resources, move the world on to a more sustainable growth path, meet people's aspirations for a better quality of life and guard against the risk of environmental tipping points. As economic analysis has taken into account the implications of the high degree of risk and uncertainty around climate-change impacts, their probably inequitable distribution and the limited substitutability of manufactured capital for environmental capital, the merits of early and strong action against climate change in particular have become more apparent (see, for example, Stern, 2008a, 2009a; Neumayer, 2007). ${ }^{3}$

However, although many governments have experimented with appropriately designed policy tools, audits of environmental policies suggest that there is much more that could be done. The OECD, for example, concludes that, "in most countries the use of scarce natural resources remains underpriced or even subsidised and the polluter pays principle is rarely implemented fully. Unsustainable subsidies are pervasive in industry, agriculture, transport and energy sectors in most OECD countries." As Albrecht (2006) noted, it is surprising how low a share of European countries' tax receipts are accounted for by environmental taxes. In the case of anthropogenic climate change, carbon pricing (implicit or explicit) is not widespread, long-standing incentive problems in promoting domestic energy efficiency remain pervasive, and public $R \& D$ spending in energy and low-carbon technologies is still low, compared with several other sectors of the global economy and with 30 years ago (Stern (2007), Chapter 16). There is, therefore, a strong case for a step change towards stronger and better designed environmental policies.

The global recession in 2008-09 focused attention on the impact of the business cycle on the prioritisation of environmental policies. ${ }^{4}$ The downturn was unusually severe. According to the IMF staff, writing in April 2009, "By any measure, this downturn represents by far the deepest global recession since the Great Depression" (IMF, 2009b). In the Schumpeter Lecture to the European Economic Association, the Deputy Governor of the Bank of England for monetary policy said, "We have seen the eruption of a systemic financial crisis of quite

programmes; reversing loss of environmental resources; (2) Reducing biodiversity loss, achieving, by 2010, a significant reduction in the rate of loss; (3) Halving, by 2015, the proportion of people without sustainable access to safe drinking water and basic sanitation; (4) By 2020, achieving a significant improvement in the lives of at least 100 million slum-dwellers.

${ }^{3}$ And recent scientific research suggests that the risks from climate change are greater than previously thought. See, for example, the synthesis report of the March 2009 International Alliance of Research Universities Congress, http://www.iaruni.org/events/past/meetings/090310_climatesummit/ClimateChangeCongress_SynthesisReport18 0609.pdf

${ }^{4}$ Environmental policies are usually discussed either in a microeconomic setting or in the context of long-run growth, in both cases abstracting from short-run macroeconomic fluctuations (see, for example, the textbook by Tietenberg and Lewis, 2008). 
unusual intensity and international reach. The nearest precedent is probably the widespread closing of international capital markets on the eve of the First World War. And associated with that, we have seen the sharpest internationally synchronised slowdown in growth in the post-war period, together with an unprecedented contraction in world trade" (Bean, 2009). Concerns have been raised about whether economies can afford the short-run costs of environmental improvements and pollution and greenhouse gas abatement. For example, before the European Union summit in October 2008, eight EU members suggested that carbon dioxide emissions targets ought to be revised in the light of current "serious economic and financial uncertainties." And the Prime Minister of Italy told a press conference, "our businesses are in absolutely no position at the moment to absorb the costs of the regulations that have been proposed."

This paper first explores the implications of the 2008-09 economic downturn for environmental policies, focusing in particular on the example of action against climate change. In Section III, the arguments for and against activist fiscal policies in general are reviewed, and the case for environmental policies that take advantage of a discretionary increase in deficit-financed spending is considered. Section IV then reviews recent fiscal stimuli in the light of the discussion. Section V offers some conjectures about the implications of this analysis for the interaction of environmental policies and business cycles more generally. Section VI draws together the conclusions: the demand-induced downturn provided a very good opportunity to undertake a necessary step change in the public spending component of environmental policies and to start working through a backlog of public investment to improve the environment. Fiscal policy should be used to improve the allocation of resources across time and space, helping to build the foundations for more vigorous, sustainable and attractive global growth. And there is little cause to delay the introduction of price signals to internalise environmental externalities. But the levels at which such signals should be set requires careful analysis; changes over the business cycle may be warranted, depending on the nature of the environmental externality and the cause(s) of the business cycle in question.

\section{IMPLICATIONS OF THE GLOBAL SLOWDOWN FOR ENVIRONMENTAL POLICIES}

The global slowdown's implications for environmental policies depend on the particular reasons why markets by themselves are unlikely to deliver as high an environmental quality as people would like, given their resources, and hence may differ according to the policy considered.

In many cases, the cause of an environmental problem lies in a market failure derived from the presence of externalities, such as those brought about by non-rivalry in consumption ('public goods' or 'bads' like human-induced climate change), by-products of production (e.g. local pollution from waste products) and network effects (e.g. in power grids). Market failures can also result from information asymmetries, such as those between landlords responsible for investing in home insulation and tenants who determine the use of heating in the home, or between informed sellers of complex products and less informed buyers. They may derive from lack of competition in markets, leading to collusive or strategic behaviour by market participants; where that reflects underlying economies of scale, technology choices

\footnotetext{
${ }^{5} \mathrm{BBC}$ news report, 15 October 2008. In the event, these reservations were overcome after discussions about how any burdens should be shared.
} 
may become path dependent, with 'good' and 'bad' equilibria being possible. And the market failures may reflect cognitive dissonance on the part of market participants, one manifestation of which is Pigou's 'defective telescopic faculty,' the tendency of individuals to discount the future too much when they make saving decisions, regretting it later (Pigou, 1932).

It is becoming more widely understood that some environmental problems, particularly climate change, are on a sufficient scale to render partial equilibrium analysis in the marginalist tradition inadequate. The economy-wide responses to both the environmental phenomenon and the policies used to tackle it need to be considered; the policies can have significant macroeconomic consequences. Correcting market failures helps to build the foundations for less environmentally damaging, more sustainable growth, and may stimulate growth itself (for example, by increasing resources devoted to $R \& D$, human capital formation and other sources of positive externalities).

Part of the policy menu should entail the provision of environmental public goods by public authorities, either directly or by mandating and financing private provision, while part should include the pricing of environmental externalities. In some cases, for example where informational asymmetries, transactions costs and network effects are prevalent, direct regulation and public provision of information are likely to be part of the policy mix as well. We argue below that the world recession warrants an increase in the public spending component of policies, but for some externalities may also imply a temporarily lower shadow price.

\section{Public spending}

A period of under-utilisation of resources due to aggregate demand deficiency is a good time to be

- investing in enhancing public capital to protect the environment; and

- focusing temporary increases in government spending on goods and services where the social return exceeds the private return (for example, because externalities have not yet been internalised by the use of market instruments).

Governments can in this sense act opportunistically, bringing forward public projects, including the provision of long-lived environmental public goods, that pass relevant criteria in order to benefit from temporarily lower opportunity costs. The argument is that there exist projects that, at the margin, become worth undertaking sooner because the downturn reduces their costs without affecting their benefits significantly. That will not be the case for all environmental projects, as explained below. And it may not be easy or desirable in practice to accelerate some projects, for example where planning approvals have to be sought, or there are likely to be bottlenecks in bringing the project to fruition due to skill shortages, or where there are simply constraints imposed by the time taken to design, build and test plant and equipment. That is more likely to be the case with large, lumpy capital-intensive projects, especially those involving specialist skills.

The stock of suitable projects is likely to be larger if new environmental problems have recently been identified or some other trigger has led to a step increase in concerns about environmental goals. In these circumstances, there is likely to be a backlog of projects to be undertaken. At a time of a demand-induced downturn, when monetary authorities are ensuring that any increases in public spending do not push up interest rates, such a backlog can be worked through with much less risk of crowding out private investment. In the case of 
climate change, the triggers have been the realisation that the risks from unmitigated greenhouse gas emissions are greater than previously thought and the need to anticipate the obligations likely to follow from international negotiations to curb emissions. Fiscal policy can be used as a risk-management tool. In the long run, under a settled environmental policy regime with no new environmental shocks, governments would only have to consider the timing of investment to make good depreciation of public goods and allow for the growth of economies. But at the beginning of a new policy regime, the composition of the public capital stock is likely to have to be adjusted - in some cases, by enough to have significant macroeconomic effects. The adoption of the new regime may thus result in accelerated public sector capital depreciation and replacement for a time. It may also entail set-up costs for regulatory and other frameworks necessary to correct market failures. The opportunity costs will be lower in a slowdown induced by sharp falls in private demand, when there are involuntarily underutilised resources.

\section{Correcting market failures}

Much environmental policy entails correcting market failures by changing the incentives facing private sector agents, rather than public finance for investment. The market failures may be directly responsible for environmental problems (e.g. the externalities of waste disposal) or inhibit their solution (e.g. the public goods nature of early-stage R\&D). Does an economic recession affect the desirability of strengthening action on this front? That depends on how the recession affects the costs and benefits of tougher action at the margin.

Recession in some cases may reduce the environmental problem under consideration and hence the potential benefits of action. For example, it is likely to reduce congestion, as lower economic activity is reflected in less movement of goods and fewer work-related journeys. A government considering a congestion charge scheme would want to set lower charges on fewer routes if the initiative coincided with an economic downturn.

Lower economic activity is likely to reduce the emission of local pollutants from industrial sources. In some cases, that may reduce marginal damage costs, for example, where the total damage done by the pollutant increases more than in proportion to the flow. But where damages are a function of the accumulated stock of pollutants, and the rate of decay is low, marginal damage costs will be less affected, as temporary changes in the flow will have a small impact on the stock.

In the case of greenhouse gases, many of which remain in the atmosphere for a very long time, the impact of an extra tonne of greenhouse gas emissions is unlikely to be reduced by recession, unless there is a significantly larger impact on the supply capacity of the economy than usual. ${ }^{6}$ Economic growth trajectories incorporated in models of marginal climate-change damage costs or marginal abatement costs are generally based on extrapolations of long-run growth trends calculated over several business cycles (see the discussion in Webster et al, 2008), so that cost estimates should be invariant to 'normal' cyclical fluctuations. But the severity of the global downturn may damage the supply capacity of the world economy sufficiently, through the destruction of capital, lower investment and less risk-taking, that global output does not return to its previous trend. If so, the global emissions trajectory may

\footnotetext{
${ }^{6}$ Here we are considering how the recession might affect the costs of a little extra greenhouse gas abatement and the benefits of further climate-impact risk reductions given a climate-change policy regime. That is not the same as considering the impact of the recession on the merits of introducing an ambitious regime - a non-marginal change, the net benefits of which will overwhelm any marginal calculus of this sort.
} 
be permanently lower than expected, making it less costly to reach any particular atmospheric concentration target (and therefore warranting a reduction in the target). Even so, the impact may be small, and outweighed by upward revisions in the projected long-run growth potential of major developing countries (Blanford, Richels and Rutherford, 2009).

Lower economic activity may also reduce households' willingness to pay for environmental improvements. With regard to congestion, for example, the opportunity cost of time is likely to be lower for some people because of unemployment or reduced hours. Credit-constrained individuals who are forced to reduce their consumption of produced good and services in a recession may also want to reduce their consumption of costly environmental goods. For non-credit-constrained people, however, one would not expect a significant impact on consumption patterns unless the recession were big enough to reduce expected lifetime income. And even if it were big enough, it is not clear how spending patterns would change. As far as we are aware, there is no empirical evidence on how willingness to pay is affected by business cycles. The literature on environmental Kuznets curves might be expected to give some clue as to how demand for environmental goods might change with economic conditions, but it focuses on cross-sectional evidence or longer time series, and in any case has not established a consensus on income effects and environmental improvements (see, for example, the discussions in Kristom and Riera (1996) and Stern (2003)).

Equity across generations comes into question when the incidence of the costs and benefits of action are borne at very different times. The mitigation of climate change provides an example, because carbon pricing and investment (foregone consumption) has to be undertaken in the near and medium term to reduce the risks of climate change damages that lie mainly in the long term. If the 2009 recession has a sufficiently large impact on growth in the near term, and consumption in the medium term is expected to bounce back towards its previous long-run trend, the policy-maker may be justified in applying a higher discount rate to long-term damages (reflecting the faster decline in the expected marginal utility of income along the optimal policy path) and hence a lower carbon price. But that depends on the extent to which the long-run trend itself is affected; a large recession may both shift down the starting point of the future long-run trend and lower its slope, with both effects tending to reduce the increase in the warranted discount rate.

We conclude from this discussion that an unusually severe and wide-ranging recession may warrant less stringency when new environmental policies are being introduced, although that depends upon the nature of the underlying environmental problem and the market failures involved. However, it is likely to reduce the opportunity costs of government expenditure associated with introducing a new policy regime, whether it is directly related to tackling a market failure (e.g. publicly funded $\mathrm{R} \& \mathrm{D}$, underwriting a new market in low-carbon products) or indirectly, through the administrative costs of introducing policy instruments to alter private sector behaviour (e.g. setting up systems to monitor pollution or verify compliance with standards). On balance, it is highly likely that significantly greater investment in natural capital, or capital associated with long-term environmental protection, is warranted during a downturn.

\section{Acting as a financial intermediary of last resort}

The 2009 slowdown is characterised by particularly severe strains on financial intermediation through banks and capital markets. Where environmental improvements require substantial private-sector investment, the private financial system is now less likely to be able or willing 
to provide the finance, even though the opportunity cost of the physical investments to be financed has fallen and the real rate of return on safe assets has dropped. Public bodies can substitute for private-sector intermediation to some extent, given that their liquidity and solvency have generally been impaired less than those of private-sector financial institutions. Some governments have tied financial assistance to banks to undertakings on the banks' part to increase lending, sometimes to particular groups of customer. The rationale for directing lending towards particular sectors is not always made clear, but if there is to be discrimination among customers, it should reflect an assessment of the social returns from the additional lending thereby brought about. That is particularly important where the provision of public goods, including environmental goods, has been delegated to the private sector through public-private finance initiatives. The financial crisis has affected capital flows to developing countries particularly severely, and there is a case for more public-sector involvement in intermediating cross-border flows to finance environmental improvements, a case that is explored further in the context of climate change in Kaminskaite-Salters et al (2009) and UNEP (2009b).

\section{The case of human-induced climate change}

Several proposals for a 'green' fiscal stimulus have been discussed and many governments have started to implement their own programmes over the past year or so. ${ }^{7}$ Their rationale derives from the considerations discussed above and the need to break the link between consumption and emissions. Many, but not all, spending measures to promote the transition to the low-carbon economy - and environmentally sustainable growth more generally - score well against criteria for good fiscal initiatives. Monetary policy, in contrast, is not well targeted at correcting market failures and managing environmental risks.

Houser et al (2009), for example, examined twelve initiatives representative of US policy proposals discussed in the run-up to the passing of the American Recovery and Reinvestment Act of 2009. They rated spending \$1 billion on each of the initiatives for speed, job creation, impact on energy prices, impact on US dependence on imported fuels and impact on carbon dioxide emissions. The first two criteria are most relevant for effectiveness in combating the economic slowdown. The authors also considered how the initiatives might contribute to tackling market failures, technology hurdles and infrastructure bottlenecks obstructing climate change mitigation and efforts to increase US energy independence. No initiative scored top marks on all criteria. House 'weatherization,' for example, did well on the criterion of timeliness, was moderately good on the criteria of employment, energy security and climate change, but was not particularly strong on energy saving (because of its capital intensity). However, battery research and development scored very well on energy savings, energy security and climate change, but not on timeliness, and thus would not be particularly effective in mitigating recession. The question of long-term finance (the 'exit strategy') is more of a concern for this type of measure.

Bowen et al (2009) similarly offered an assessment of a wide range of measures against the criteria of long-term social return, ability to 'lock in' low-carbon technologies, timeliness, likely domestic output or employment multiplier, targeting parts of the economy with slack and existence of an exit strategy. Like the US study, this found that the scores for proposed measures varied considerably. Not all 'green' proposals scored well against the criteria for

\footnotetext{
${ }^{7}$ Examples of proposals include Bowen et al (2009), Edenhofer and Stern (2009), Pollin et al $(2008,2009)$ and Houser et al (2009)
} 


\section{JANUARY DRAFT}

effectiveness against the slowdown, with large-scale infrastructure in the energy sector suffering from long planning and implementation lags but energy efficiency improvements in buildings scoring highly.

The promotion of energy efficiency in buildings does well against fiscal criteria partly because it is an example where tackling an underlying market failure unlocks multiple benefits. Wade et al (2000), in their review of 44 energy efficiency programmes in nine EU countries, found that information and education campaigns and innovative institutional programmes had combined high employment gains, low government expenditure and costeffective policy instruments - an example of how the returns to public expenditure associated with correcting information problems can be high. For the same reason, encouraging adoption of smart metering of electricity use can be very beneficial, although the employment effects are likely to be lower and timeliness may be inhibited by the need to develop technologies further.

The assessments of 'green' measures also reflect a judgement that spending on the transition to the low-carbon economy is likely to increase the demand for labour at a time of high involuntary unemployment. Kammen et al (2006) pointed out that renewable energy industries appear to be more labour intensive than the existing energy sector, particularly at the initial construction, manufacture and installation stage that is most relevant for a shortterm fiscal stimulus. Fankhauser et al (2008) concluded from a review of labour intensity estimates in the literature that a shift from high-carbon to low-carbon activities is likely to lead to net job creation, although there is considerable uncertainty about how labour productivity will evolve and about the impact of induced changes elsewhere in the economy. Roland-Holst (2008) provided evidence from California's lengthy experience of promoting energy efficiency that it has been effective in generating net job creation, taking into account the jobs created by the diversion of spending from energy to other goods and services. Pollins et al (2009), using an industry input-output table approach and assuming widespread unemployment due to deficiency of aggregate demand, argued that US\$ 1 million extra spending on clean energy will generate roughly three times more jobs than the equivalent spent on fossil fuel industries, with a larger proportion of low-skill jobs in the skill mix. These results suggest that a switch to clean energy from fossil fuels is likely to be relatively labour intensive. In the long run, that may reduce measured labour productivity, abstracting from the benefits of avoided climate change, but in the short run the switch should be helpful in reducing historically high unemployment rates. ${ }^{8}$

From the point of view of the environmental objective of halting human-induced climate change, some of the measures proposed were designed to help tackle market failures, particularly in the provision of $\mathrm{R} \& \mathrm{D}$, and information about energy saving. But, as Houser et al (2009) wrote, "Green recovery efforts will only make a meaningful dent in US emissions if they complement comprehensive climate policy." The key element of policy missing in the US case, and indeed worldwide, has been comprehensive pricing of greenhouse gas emissions. This Section argues that the global slowdown does not warrant delaying the introduction of emissions pricing, so it is reassuring that, at the time of writing, several countries, including the USA, are considering implementing cap-and-trade schemes. These would greatly amplify the effectiveness of some of the fiscal initiatives, such as tax credit incentives for investment in low-carbon plant and equipment.

\footnotetext{
${ }^{8}$ The story is complicated by the fact that the switch entails the initial set-up of a new energy infrastructure. The employment impact of operating and updating that infrastructure once established is likely to be quite different. And induced technical progress is likely to reduce the labour intensity of low-emissions technologies over time.
} 
However, the experience of the EU Emissions Trading Scheme, in which the onset of the recession brought about a decline in the carbon price of more than $70 \%$ from the end of June 2008 to mid-February 2009, gives some cause for concern. ${ }^{9}$ That is a much larger drop than any impact the recession might have had on the marginal damage costs of carbon dioxide, ${ }^{10}$ implying that low-cost abatement opportunities that would otherwise have been taken will have been neglected. The carbon price has in general been very volatile, which is not unusual in cap-and-trade schemes to control pollutants, because of the inelastic supply of quotas (Metcalf, 2009). Some of the volatility is likely to be due to the youth of the market; greater depth and breadth would reduce liquidity problems and strategic behaviour of participants. It also seems to have been correlated with the wholesale prices of natural gas (one of the most volatile commodity prices), oil and coal, reflecting variations in energy demand and the scope for switching commercial energy supplies among sources (Mansanet-Bataller, Pardo and Valor, 2007; Geman, 2005). That is not to argue that cap-and-trade is necessarily inferior to greenhouse gas taxation; there are strong arguments for a tradable quota system (see Stern (2008b), Chapter 6). But there is a case on efficiency and equity grounds for considering whether mechanisms such as banking, borrowing, price caps and price floors are needed to dampen swings in carbon prices (Fankhauser and Hepburn, 2009).

\section{ARE ACTIVIST FISCAL POLICIES WARRANTED IN RESPONSE TO THE ECONOMIC DOWNTURN?}

Section II made the case for an increase in deficit-financed environmental spending as part of this stimulus. But the case for a discretionary increase in deficit-financed government spending on public goods to protect the environment fails if such activist fiscal policy is the wrong response to the downturn, the issue to which we turn next.

\section{The analytical debate}

The general case for an active fiscal stabilisation policy can be made within the framework of modern New Keynesian macroeconomic theory (Andersen, 2005). Various market failures cause economies to adjust inappropriately to shocks - for example, prices may not be altered quickly enough (perhaps due to 'rational inattentiveness' as discussed by Ball et al, 2003). To the extent that policy-makers can respond to those shocks in a way that private markets cannot, there is scope for fiscal policy as long as activity is affected by aggregate demand in the short run. In the aftermath of an asset price boom and bust, at a time of increased uncertainty and business pessimism, it is very likely that private sector saving rates will increase, reflecting precautionary saving and the desire to rebuild financial wealth. There are, however, constraints on how far nominal interest rates and how fast inflation expectations can change to offset this change in behaviour. In these circumstances, fiscal deficits have to increase to offset an excess of planned private sector saving over planned investment at full employment and avoid equilibrium being brought about by further falls in income. ${ }^{11}$

\footnotetext{
${ }^{9}$ Futures price for the December 2009 contract, European Climate Exchange.

${ }^{10}$ That assumes that the recession does not trigger sharp downward revisions in estimates of both marginal damage costs and abatement costs of emissions. The comments of politicians suggest the contrary is the case.

${ }^{11}$ Andersen generally preferred automatic stabilisers to discretionary fiscal policy, because the latter requires considerable knowledge about the source of shocks to, and the structure of, the economy. But he argued that it is appropriate "in the case of 'large' shocks or situations where the economy is caught in an expectations trap keeping output at a permanently low level."
} 


\section{JANUARY DRAFT}

Yet for much of the past 25 years or so, economic orthodoxy has been sceptical about the efficacy of fiscal activism, preferring monetary policy as a countercyclical tool. Feldstein (2002) believed that "there is now widespread agreement in the economics profession that deliberate countercyclical discretionary policy has not contributed to economic stability and may have actually been destabilizing in the past."12

Taylor distilled some of the key arguments in a paper entitled 'Reassessing discretionary fiscal policy' (Taylor, 2000):

- The implementation lags of monetary policy are usually shorter than for fiscal policy.

- Fiscal policy actions are more difficult to reverse, partly because of political inertia, if new information warrants it, whereas monetary policy can be adjusted rapidly.

- Active fiscal policy would make the work of monetary policy-makers more difficult, as fiscal variables would be more difficult to forecast.

- Automatic changes in fiscal stances (the so-called 'automatic stabilisers') are more predictable and work more quickly than discretionary changes, and are often much larger.

- Fiscal policy can have larger structural side-effects than monetary policy, for example, by changing effective tax rates and the deadweight losses associated with them.

- In practice, discretionary fiscal policy, at least in the United States, has not in general been countercyclical. ${ }^{13}$

Taylor did, however, concede that discretionary increases in government spending or reductions in taxes could stimulate aggregate demand. Some economists go further, drawing on Barro's proposition that government bonds do not constitute net wealth, so that the substitution of debt issuance for tax revenues (i.e. tax cuts and increased deficit financing) should not affect private sector spending - the principle of Ricardian equivalence (Barro, 1974). Taxpayers anticipate fully the increased taxes that will have to be paid in the future if the government's intertemporal budget constraint is to be satisfied. Increases in government spending might more than crowd out private spending, if financed by distortionary taxes (e.g. income taxes) (Baxter and King, 1993). Lucas (1987) argued that business cycles are not likely to be very costly in any case, from which it follows that macroeconomic policy activism is unnecessary and (because of tax-induced distortions) potentially worse than the phenomenon it is trying to correct.

Another criticism is that active fiscal policy in the absence of an accommodating monetary policy is likely to push up interest rates, thus crowding out private sector spending to some extent. In a small open economy with a flexible exchange rate and capital mobility, fiscal policy will be completely ineffectual, as illustrated in the well-known Mundell-Fleming model (see, for example, Blanchard (2009)). And if lenders to government begin to suspect that the government may not have the capacity to repay the real value of public-sector debt in

\footnotetext{
${ }^{12}$ But the consensus did not reflect an intensive debate. Andersen noted that "recent literature devotes very scant attention to fiscal stabilization policy." One honourable exception was the Oxford Review of Economic Policy, Vol 21, No 4, 2005, in particular the editorial essay by Allsopp and Vines, which concluded that there was little basis for the presumption in the 'new consensus' that fiscal policy should have no macroeconomic role in 'flexible inflation targeting regimes.'

${ }^{13}$ Taylor remains sceptical, while advocating fiscal reforms to provide "appropriate government services, including infrastructure and defense" and the use of automatic stabilisers (Taylor, 2009).
} 


\section{JANUARY DRAFT}

full, default risk premia and/or inflation premia on government bonds may rise sharply, exacerbating the tightening of credit conditions.

However, even many sceptics accept that there are some circumstances when active fiscal policy may be appropriate. Taylor, for example, discussed the case where the nominal interest rate is approaching its lower bound of zero, so that monetary policy is less easy to implement, particularly if the general level of prices is expected to fall. That scenario became relevant in Japan a decade ago (Krugman, 2005) and also applies today in the major industrial countries. Christiano et al (2009) showed that, whenever the zero bound on nominal interest rates is binding, the government spending multiplier can be much greater than one (i.e. there is crowding in of private spending, not crowding out, which would be reflected in a multiplier of less than one). Similarly, if monetary policy prevents nominal interest rates from rising in the face of a fiscal expansion, the nominal exchange rate will not be affected, so that net export demand will not be crowded out. ${ }^{14}$ Also, the recent shocks to capital markets and banking systems have impaired the functioning of the transmission mechanism from central banks' actions to nominal spending, making it less predictable and reducing the comparative advantage of monetary policy. The apparent inability recently of monetary policy in its 'flexible inflation targeting' guise to prevent asset price booms and busts with adverse macroeconomic consequences has also cast some doubt on the adequacy of central banks' interest rate instrument alone to regulate the macroeconomy. ${ }^{15}$

\section{Empirical evidence}

Not only is there a theoretical case for activist fiscal policy in certain circumstances; there is also empirical evidence in its support. For example, the IMF investigated how effective fiscal policy had been in responding to downturns in economic activity, particularly recessions (Hemming, R, Mahfouz, S, and A Schimmelpfennig, 2002). The impact of fiscal expansions appeared to have varied widely across countries and time, but certain common features emerged. Expansions had tended to be more effective when:

- There was excess capacity;

- The economy was relatively closed;

- Public spending was a relatively large share of the economy;

- Fiscal expansion was accompanied by monetary expansion.

The authors found little evidence of 'crowding out,' either directly or indirectly through interest rate increases or exchange rate appreciation. Baldacci et al (2009), in a study of 118 episodes of banking crisis, concluded that timely countercyclical fiscal measures contributed to shortening the length of the episodes by stimulating aggregate demand. ${ }^{16}$ Freedman et al (2009) drew attention to the wide range of estimates of fiscal multipliers in the empirical

\footnotetext{
${ }^{14}$ This assumes that expected inflation or deflation do not diverge significantly across countries.

${ }^{15}$ Nor is monetary policy necessarily less discriminatory than fiscal policy across sectors; interest rate changes affect some industries and types of spending more than others, while some fiscal policy tools, such as a broadbased value-added tax, may have a more neutral effect. Neither is necessarily targeted at the underlying causes of particular business cycles.

${ }^{16}$ Some studies have found that fiscal contractions can sometimes be expansionary (Giavazzi and Pagano, 1990; Alesina and Perotti, 1995), but this appears to reflect special circumstances where the credibility of governments' fiscal frameworks had previously come into question. Sutherland (1997) showed that very high initial public debt could reverse the impact of fiscal policy.
} 
literature, but noted that they tended to be higher for more closed economies, for expenditure increases rather than tax cuts, and where monetary policy had been accommodative. ${ }^{17}$

The empirical studies are by no means conclusive and it remains difficult to determine what firms and households would have done (and hence how much, if any, crowding out was induced) if fiscal policies had been different, not least because that behaviour is influenced by unobserved expectations about the macroeconomic policy regime and the fiscal stance. The continuing debate about fiscal policy is a reminder that amending 'tax and spend' policies is not always the appropriate response to economic shocks. But the theoretical and empirical literature suggests that the particular circumstances of this economic downturn make it one of the occasions on which fiscal activism is more likely to be effective.

\section{The 2008-09 economic downturn}

The economic downturn surprised forecasters. As late as July 2008, the IMF was forecasting that world GDP would grow by 3.9\% in 2009 (see Table 1). By April 2009, it was predicting that world GDP would contract by $1.3 \%$ - a downward revision of five percentage points in only nine months. By comparison, the slowdown of 2001-02, while a surprise, was less of a shock. Between May 2001 and December 2001, the IMF revised down its forecast for world growth in 2002, but only by 1.4 percentage points. All regions of the world have been affected this time, in contrast to the slowdown earlier in the decade, when China's growth, for example, was little altered. The IMF projections at the time of writing are slightly less pessimistic, especially for 2010, but they reflect the extent of the fiscal and financial measures taken globally over the past year.

\section{[Table 1 near here]}

The downturn is unusual in its origins as well as its severity and scope. Its genesis lay neither in an adverse supply-side shock like the oil price increases of the early and late 1970s nor in a reduction in nominal demand engineered by central banks worried about inflation getting out of control. Rather, it has its roots in falls in confidence among households and firms, triggered initially by house price falls and problems in the US financial system, and amplified by the subsequent malfunctioning of banking systems and capital markets around the world. ${ }^{18}$ Thus it seems to correspond to the canonical case of a business cycle triggered by a collapse in confidence after a period of exuberant optimism, a fall in what Keynes called 'animal spirits' and a sharp increase in liquidity preference. The increase in the likely excess of planned private saving over planned investment at full employment has been exacerbated by the desire of countries like China to accumulate foreign currency reserves.

\footnotetext{
${ }^{17}$ Some of the foundations of the Barro-Lucas argument against fiscal activism are also brought into question by the empirical evidence. According to Ricciuti (2003), most studies have found that Ricardian equivalence does not hold in practice, particularly in economies where many households cannot smooth their consumption over time because of credit constraints. Sarrantis and Stewart (2003) estimated that, on average over 20 OECD countries, $70 \%$ of households were credit constrained. The representative, infinitely lived, agent model in which the principle of Ricardian equivalence is derived does not incorporate credit markets and overlapping generations easily.

${ }^{18}$ The Chief Economist of the Bank of England put it thus: "Unlike the recessions of the late twentieth century, this twenty-first century version is not the result of deliberate, but belated, attempts to slow the expansion of money spending in order to bring down inflation from very high levels. This recession has at its heart a crisis in the banking system; a crisis that has strangled the supply of credit and undermined public confidence." (Dale, 2009)
} 
This diagnosis of the causes of the downturn in the world economy is relevant for the choice of policy instruments to help bring it to an end. We argue that a global fiscal response to the crisis was appropriate because the crisis primarily reflects a sharp slowing in nominal demand growth, not counter-inflationary policies or adverse supply shocks; it is global; monetary policies are accommodative but of less predictable benefit by themselves; and, judging by risk premia on government debt, initial levels of debt are not calling into question the long-run sustainability of fiscal frameworks. Overall, we agree with Freedman et al (2009): “The evidence provides some support for the view that, in the current environment where monetary policy remains accommodative, a well-executed global stimulus could provide an appreciable boost to the world economy in crisis." And, at the time of writing, the upward revisions in projections for growth in 2010, after many governments have implemented discretionary fiscal stimuli to a greater or lesser extent, suggests that the measures have indeed been helping.

\section{Criteria to assess fiscal initiatives}

However, not all discretionary fiscal policies are equal. Proposals to strengthen environmental policies now need, like other initiatives, to be judged against performance criteria. As the Institute for Fiscal Studies has argued (IFS, 2008), a good fiscal stimulus should be "targeted, timely and temporary.",

The second two criteria are more straightforward than the first. Timeliness is important because the stimulus will be more effective, the sooner it is implemented after the initial shocks to demand, moderating the downward multiplier effect on investment. This criterion should in part meet Taylor's concerns about implementation lags and past failures to ensure that discretionary fiscal policy would be countercyclical. Lane (2003) provided cross-country evidence that those concerns have merit, given the political economy of fiscal policy.

The stimulus should be temporary, being gradually withdrawn when private-sector nominal demand growth begins to close output gaps. This criterion acknowledges Taylor's objection that fiscal policy changes are difficult to reverse. Again, the political economy challenge is significant, but laying out the arguments at an early stage may help to tie governments' reputations to the success of later fiscal stabilisation. If the stimulus were to last too long, it would risk pushing up default and inflation premia on government bonds, as investors became more worried about governments' ability to service their rising debts. Some countries have less scope for fiscal measures, because they have a high structural full-employment budget deficit or large contingent liabilities, a point made strongly by Buiter (2008). As the IFS has pointed out, a temporary stimulus need not entail temporary policy measures, but it does require an exit strategy to finance any long-term policy measures when recovery comes. And that strategy should take into account any impacts of the downturn on likely tax revenues and liabilities in the longer term - for example, in the UK case, the probable decline in revenues from taxes on the banking sector and on asset transactions. But fiscal sustainability does not necessarily require rapid stabilisation of government debt/GDP ratios as long as the long-term fiscal framework retains its credibility (Leith and Wren-Lewis, 2005).

\footnotetext{
${ }^{19}$ The IMF discusses a similar but longer list of criteria: that the fiscal stimulus should be timely, large, lasting, diversified, contingent on subsequent economic developments, collective and fiscally sustainable. By 'lasting,' the IMF mean persisting until recovery is under way. The size of the stimulus should be large because of the magnitude of this downturn. Contingency and fiscal sustainability reflect the 'temporariness' criterion in the text. See Spilimbergo et al (2008).
} 
Targeting is a more difficult issue. One criterion is to focus spending increases and tax cuts where they would have the most effect on aggregate demand. Hemming, R, Kell, M, and S Mahfouz (2002), in a review of OECD experience, found that short-run fiscal multipliers tended to be in the range 0.6 to 1.4 for spending increases, while for tax cuts they tended to be significantly lower, lying in the range 0.3 to 0.8 . Some more recent work at the IMF has tried to take into account the particular circumstances of the downturn. Freedman et al (2009) compared the impact of increases in lump-sum transfers to households, reductions in taxes on labour incomes, increases in government consumption and increases in transfers targeted on credit-constrained consumers. ${ }^{20}$ They found that a dollar spent on government investment had a bigger cumulative effect on GDP than a dollar spent on targeted transfers, which in turn were more effective than general lump-sum transfers or tax cuts (Chart 1). ${ }^{21}$ That reflects how saving from additional income by non-credit-constrained households reduces multipliers.

\section{[Chart 1 near here]}

However, a second criterion for targeting is the social return obtained. Creating private or public capital that generates social returns over time is preferable to the Keynesian caricature of digging holes in the road and filling them in again. This criterion aims to turn Taylor's objection to the unintended structural side effects of fiscal policy changes on its head measures are to be preferred if they improve the functioning of the economy. As Baxter and King (1993) showed, if public investment is productive and enhances the productivity of private investment, that can significantly increase the long-run government spending multiplier. Baldacci et al (2009) found that increased public consumption was more effective than increased public investment or tax cuts in shortening episodes of banking crises, but that public investment provided a bigger boost to output growth after the crisis ended. The costs and benefits of deficit-financed projects need to be assessed just as with any public project. In a demand-induced slowdown, the opportunity costs of many products and factors of production are lower than at full employment and full capacity. But public spending will also have incur costs if monitoring spending is expensive and rent-seeking is encouraged.

A third criterion for targeting is to avoid inhibiting the economy's adjustment to the shocks that triggered the downturn. Thus, for example, one of the causes of the downturn appears to have been overinvestment in the US and UK housing markets. It may be appropriate for the relative pay of workers with skills specific to the housing industry to fall, signalling the need to reallocate workers among industries in the longer term. Public works that involve temporary employment of such workers - for example, in home insulation to improve domestic energy efficiency - should take that need for long-run adjustment into account. The difficulty here is distinguishing between temporary and permanent shocks. Manufacturing employment is likely to be more cyclical than services employment because of inventory cycles, so a decline in relative manufacturing employment is to be expected in the downswing of a business cycle.

The criteria discussed so far have focused on taxes and public spending. But there is another dimension of government policy to combat recession that may involve increasing government

\footnotetext{
${ }^{20}$ They used a multi-country structural model in which firms and households optimise, but in which some consumers' spending is restricted to their disposable incomes ('hand-to-mouth' consumers). This assumption, combined with overlapping generations, frees the model from Ricardian equivalence.

${ }^{21}$ Note also how monetary accommodation enhances the impact and duration of the fiscal stimulus in their simulations. However, they assume that governments can actually disburse the tax cuts, transfers and spending rapidly, which may not be the case, especially for public investment.
} 
liabilities, at least temporarily. The serious impairment of financial intermediation in the downturn warrants government action to restore confidence to credit markets. That may entail acting as financial intermediary of last resort in cases where the benefits of the project being financed are contingent on future government actions or have significant social benefits - in both cases, the government may be in a better position than a balance-sheet-constrained financial intermediary to monitor project performance and underwrite private-sector investment. That is likely to be the case in large-scale environmental projects, particularly projects to mitigate climate change, where private-sector involvement is likely depend on expectations about the carbon pricing regime and other aspects of climate-change policies, both locally and globally, over a long time horizon.

In summary, key criteria include:

- Timeliness

- The existence of an 'exit' strategy for when fiscal consolidation becomes necessary: unwinding the policy and/or introducing private finance or taxes

- A substantial multiplier effect on aggregate demand

- A high social return and (so that public action is necessary) a lower private return

- The ability to facilitate rather than slow structural adjustments necessary for macroeconomic recovery

\section{THE SCALE AND CONTENT OF RECENT FISCAL STIMULUS PACKAGES}

In practice, governments have in general accepted that there was a case for a discretionary fiscal stimulus in the particular circumstances of the 2009 slowdown. Forecasts suggest, however, that the size of the global stimulus has been insufficient to prevent growth falling well below trend in 2009 and 2010. In December 2008, the IMF's Managing Director suggested that, for the G20 countries, a discretionary fiscal stimulus amounting to around $2 \%$ of annual GDP would be appropriate in view of the severity of the downturn expected. Subsequently, in a succession of revisions until July 2009, the IMF reduced its projection of world GDP growth in 2009 by 3.6 percentage points, despite the announcement of fiscal packages in many countries (see Table 1). The projection for world growth in 2010 was revised down by 0.5 percentage points between January and July 2009, leaving it at less than half the level achieved in 2007, although it has subsequently been revised upwards again as signs have emerged of recovery and several countries have started to report positive, if anaemic, quarterly growth again.

In March 2009, it was estimated that announced discretionary measures would increase G20 annual budget deficits by around 1.2 percentage points of GDP on average over 2008-10 compared with budget deficits in 2007 (IMF, 2009a), somewhat less than recommended by the IMF. $^{22}$ But taking into account automatic stabilisers and non-discretionary structural changes in budget deficits, the fiscal stimulus was estimated to be of the order of 3.8 percentage points relative to 2007 - substantial but insufficient to stop world output falling further below trend in 2009-10. In retrospect, for those accepting the case for activist fiscal policy, it appears that there was room for a significantly larger stimulus overall than has actually been put in place. Table 2 , however, makes it clear that the scope for discretionary deficit-financed spending varied widely across countries. The sixth column shows how automatic stabilisers have contributed more to the stimulus than in the United States or China,

\footnotetext{
${ }^{22}$ However, the IMF Managing Director's recommendation was not clear about the length of time over which the discretionary stimulus should be spread.
} 


\section{JANUARY DRAFT}

leaving less room for discretion. And some countries, including notably the United Kingdom, have seen a sharp deterioration in their structural budget balance (eighth column).

\section{[Table 2 near here]}

The proportion of fiscal stimuli devoted to environmental measures is difficult to calculate accurately. Government announcements have not always been precise about how additional spending is to be divided up among different objectives or over what period disbursements are expected to take place. Some of the changes in government budgets induced by the slowdown may be associated with environmental spending (e.g. increases in subsidies to mass transit as operating deficits rise). And the classification of what counts as environmental spending is not a straightforward issue. For example, several governments have announced large investments in rail infrastructure. That may reduce urban congestion and pollution from private cars but stimulate overall spending on fuel for transport. The impact on greenhouse gas emissions depends on the fuel mix on the rail network. In France, where the high-speed rail network is electrified and the extra electricity is expected to be generated by nuclear power, a reduction is to be expected. Where diesel or electricity produced from coal-fired power stations is used, the outcome is less clear, especially when the emissions associated with building the rail network are included.

Nevertheless, it is possible to obtain a broad picture of the environmental component of discretionary measures. HSBC (2009) has tracked stimulus initiatives and attempted to identify 'green' spending broadly defined to include investment or tax incentives for lowcarbon power (primarily renewables and carbon capture and storage), enhanced energy efficiency and water and waste management (Table 3). Globally, the largest sums have been promised for improvements in railway networks, electricity grids and building energy efficiency. Spending plans for renewable energy development have amounted to less than $10 \%$ of the total. Among major economies, the proportion of the total stimulus plans accounted for by 'green' measures ranged from $1.3 \%$ in Italy to $78.8 \%$ in South Korea. There has been little correlation between increases in green spending and greenhouse gas emissions per head.

\section{[Table 3 near here]}

Overall, as of August 2009, HSBC identified commitments amounting to around US\$ 500 billion to 'green' objectives, around two thirds of which was likely to be disbursed in 2009 and 2010. That was nearly $20 \%$ above what had been announced up to six months earlier. However, disbursements had been slower than expected, highlighting the problems of timeliness with many environment-related projects. HSBC noted that early spending had been focused on infrastructure sectors, with very little spending on the transition to lowcarbon energy. That may reflect planning lags and the need for more research, experience and 'learning by doing' in the application of renewable technologies, suggesting that this component of the transition to a low-carbon economy is difficult to hurry and hence should not be thought of as a suitable candidate for opportunistic temporary increases in public spending. But it is perhaps surprising that more action has not been taken to promote greater energy efficiency and to harvest other 'low-hanging fruit' in the battle to reduce greenhouse gas emissions.

To put the magnitude of planned spending in perspective, consider the investment likely to be necessary to move the global economy on to a low-carbon trajectory consistent with the 
aspiration to keep global warming to less than $2{ }^{\circ} \mathrm{C}$. McKinsey \& Company (2009) estimated that the annual incremental investment costs required would be $€ 320$ billion by 2015 . That is a similar to the International Energy Agency's estimate of the likely incremental costs of power generation required for greenhouse gas abatement (IEA, 2008) and the UNFCCC's estimate of the gross extra investment flows required by 2030 (UNFCCC, 2007). ${ }^{23}$ Yet public and private spending on sustainable energy fell by over $20 \%$ in the second half of 2008 , compared with a year earlier, as the recession hit, according to New Energy Finance, who are projecting a fall of 26-38\% in investment in green energy in 2009 (New Energy Finance, 2009). These figures suggest that the extra 'green' spending, while representing a significant boost to environmental spending by public authorities and hence a strengthening of environmental policies, is insufficient to address the challenge of climate change, the biggest environmental problem that governments face. In addition, some of the discretionary government spending, such as spending on the expansion of road networks, may have harmful environmental side effects.

\section{ENVIRONMENTAL POLICY AND BUSINESS CYCLES IN GENERAL}

There was a very strong case for taking the opportunity of the 2009 global slowdown to bring in more aggressive environmental policies and in particular to undertake public spending on environmental public goods and on correcting market failures. But the lessons for how policy instruments should be adjusted in the face of business cycles, given an effective environmental policy framework, are not so obvious.

First, one possible objection from environmentalists to increased public spending on environmental objectives in a downturn is that it will also increase spending more generally throughout the economy, including environmentally damaging consumption and investment. This multiplier effect is usually regarded as a benefit (and one of the factors changing the cost-benefit calculus in favour of temporarily higher spending on public goods). But it could generate more adverse environmental side effects and contribute to a further run-down of natural capital. In several countries, investment in human and manufactured capital has not been sufficient to replace the depletion of natural capital and questions remain about the substitutability of the former for the latter (Arrow et al (2004); World Bank annual World Development Indicators; Neumayer (2003)).

However, a recession is a very inefficient way of reducing the environmental damage associated with economic growth, given the indiscriminate capital scrapping and involuntary unemployment that it creates. Instead, the market failures allowing growth to be 'immiserising' need to be tackled at the same time as growth is promoted. ${ }^{24}$ As Munasinghe (1999) writes about macroeconomic reforms, "Unintended adverse side effects occur in many cases - when such growth-inducing reforms are undertaken while neglecting other policy, market or institutional imperfections. The remedy does not generally require reversal of the original economy-wide reforms, but rather the ex ante implementation of additional complementary measures that remove such imperfections." 25 That means that stimulus spending should prioritise public investments in preserving natural capital, including the

\footnotetext{
${ }^{23}$ The UNFCCC figure is lower if one nets off the investment spending saved by reducing fossil fuel generation and supply and the size of the capital stock for energy transmission and distribution.

${ }^{24}$ Bhagwati (1958) introduced the concept of immiserising growth, where economic growth makes a country worse off. His focus was on induced changes in the terms of trade, but unpriced environmental externalities can give rise to the same phenomenon.

${ }^{25}$ See also Mäler and Munasinghe (1996).
} 


\section{JANUARY DRAFT}

Earth's capacity to sequester greenhouse gases, over increased consumption. It is also likely to entail significant long-term changes in relative prices and in the trade-off between work and leisure, particularly in industrial countries, and the endowment of future generations with more natural capital and less manufactured capital than would be generated in a market system without policy intervention. In the case of climate change, promoting development and avoiding immiserising growth also means breaking the link between consumption and greenhouse gas emissions. ${ }^{26}$

Second, business cycles differ in their causes. There is a weaker case for extra deficitfinanced spending in downturns triggered by adverse supply-side shocks than in those triggered by autonomous falls in private sector demand. And there is even less of a case when the slowdown results from policy-induced declines in nominal demand (for example, to bring inflation down to target within an inflation-targeting framework). Financial crises associated with some business cycles change the transmission mechanisms of monetary and fiscal policy, in ways that are still being explored. So the scope for opportunistic rescheduling and front-loading of environmental investments depends on the particular circumstances of the slowdown.

Third, the propagation of business cycles is still not fully understood. The real business cycle approach associated with Lucas stresses productivity shocks and often rules out involuntary unemployment by assumption. The new Keynesian approach that emphasises nominal rigidities does not yet share a consensus about the source of those rigidities or whether they affect wages or prices more. And microeconomic evidence suggests that prices may not be as rigid as the macro models have to assume to replicate key correlations in the macro data. The microeconomic foundations of macro models in this tradition are not always formulated in a manner conducive to carrying out welfare analysis in a second-best context. Policy experiments are usually confined to monetary policy, or in a few cases, budgetary policy, but not tax instruments to tackle the underlying causes of business cycle fluctuations in response to shocks. So far, there has been little study of how different assumptions about the nature of business cycles might affect optimal environmental policies, although, as discussed below, some steps have been taken in this direction. ${ }^{27}$

Fourth, business cycles are difficult to predict and it takes time to recognise when a new shock has taken place. As business cycles are stochastic, it is very difficult for public authorities to plan in advance to schedule public spending projects in such a way as to iron out the troughs and peaks in private sector demand and take advantage of periods of lower opportunity costs. Similarly, even if, in principle, it were desirable to adjust environmental taxes in response to the shock, it would be difficult to do so in a timely manner, given government budgetary processes.

Fifth, the scope for fiscal stimulus depends on how open the region is that is contemplating action. There are greater constraints on small, open economies reacting to region-specific shocks. The same holds true for the 'green' component of discretionary measures.

\footnotetext{
${ }^{26}$ Arrow et al (2004) discuss the 'over-consumption' view from an economic and ethical perspective. Sinn (2008) discusses the welfare implications of leaving more natural capital to future generations when those generations are likely to be better off than the current one.

${ }^{27}$ It should also be noted that business cycle models designed for typical industrial economies are unlikely to be appropriate for all countries. Given that many environmental problems are more acute in developing countries, models incorporating relevant characteristics (e.g. shifting labour supply between formal and informal sectors) would be useful.
} 
Sixth, the implications of business cycles for the introduction of a new environmental policy regime and the implications for policy instrument settings within a settled regime may differ. The former has been the primary focus of this article, but the latter should be the main focus once stronger policies are in place. As far as policies to halt climate change are concerned, the case for introducing a regime to price carbon as soon as possible is strong, partly because of the lower opportunity costs of any associated set-up expenditures. But how carbon prices should move relative to other prices over the business cycle is a different question. It is also potentially an important one, given that carbon taxes are unlikely to be adjusted in a timely and rapid fashion in response to business cycle shocks but carbon prices in a cap-and-trade system are likely to respond sharply.

It was argued above that some fall in the carbon price may be appropriate in a sharp recession; that reflects a change in the trade-off between the welfare of current and future generations, not an administered cut in the carbon price as part of a general fiscal stimulus. In general, environmental taxes are not good candidates for use as fiscal tools, because temporary changes in them for purely fiscal reasons are likely to distort relative (tax-inclusive) prices away from their relative shadow prices. In the case of the carbon price, this observation is reinforced by the fact that energy prices tend to be more flexible than prices of more labourintensive goods and services, so that falls in the carbon price in the face of a demand-induced recession would exacerbate the distortion of relative (tax-inclusive) prices in the economy as a whole. However, as Section II suggested, there are circumstances when relative shadow prices are likely to be affected by macroeconomic downturns, so focusing on 'getting prices right' and forswearing the use of environmental taxes as fiscal regulators does not necessarily imply that those taxes should be invariant to the business cycle.

One area of research that might shed some light on how, in principle, environmental taxes in general and the carbon price in particular ought to move over the business cycle is the socalled 'double dividend' literature. This literature emphasises the principle that, where there are multiple market imperfections and first-best policy tools such as lump-sum taxes and subsidies are not available, the consequences of environmental policies for other policy objectives need to be considered as well. Thus, in particular, the revenues raised from environmental taxes can be used to reduce distortionary taxes elsewhere in the economy (Bovenberg and Goulder, 2002). The starting point matters. If environmental taxes are introduced from scratch into a world where all other taxes have already been set optimally, given the constraints present, this 'double dividend' will not be available.

Bovenberg and Van der Ploeg (1996, 1998) explored the interaction of environmental taxation with rigid real consumption wages, a market distortion that gives rise to involuntary unemployment. Fiscal constraints were assumed to rule out employment subsidies to correct this problem. They found that introducing environmental taxation from scratch could improve the environment (the Pigovian aspect), increase employment (by allowing distortionary labour taxes to be reduced) and increase returns to other fixed factors of production (e.g. entrepreneurs). The implication is that putting in place a new environmental policy regime at a time of unemployment caused by rigid consumption wages would be welfare improving along several dimensions (in the authors' terminology, generating a 'green', 'pink' and 'blue' dividend respectively) - potentially relevant in the current conjuncture. However, starting from a position where environmental taxes were already significant, if not high enough, the likelihood of achieving a triple dividend was much lower. The absence of a fixed factor of production (e.g. because of the openness of the economy or the longer time horizon of the 
thought experiment) made it more likely that the incidence of the environmental tax would be on labour, reducing employment. So raising environmental tax rates in response to a shock that had increased unemployment would not necessarily be a good idea.

Chang et al (2009) analysed a real business cycle model that included both pollution externalities on welfare and production and monopoly power among firms. They found that the socially optimal pollution tax should fall in periods of recession in order to stimulate employment. But the authors' description of this as a "Keynesian-like stabilizer designed to mitigate business cycle fluctuations" seems a misnomer given the lack of any Keynesian characteristics in their model. Once again, though, the model illustrates how environmental taxation should not be considered in isolation from other policy instruments and distortions in the economy when general equilibrium considerations could be important.

In the case of climate-change policies, the standard Pigovian approach leads to the conclusion that the carbon price should be invariant to short-run macroeconomic shocks that shift around the marginal abatement cost curves facing emitting firms, although the accumulation of shocks may warrant adjusting the price (Pizer, 2002; Newell and Pizer, 2003; Stern, 2007). But carbon pricing may also have other economy-wide effects. For example, a fall in carbon prices in a demand-induced downturn reduces the burden of climate change mitigation on the cohort hit by the downturn (attractive on equity grounds), while also altering relative prices of fossil-fuel energy and other inputs to production, some of which may otherwise suffer from nominal rigidities. But that may exacerbate misallocation of resources across sectors and firms while helping macroeconomic adjustment. Although the volatility of carbon prices in the EU Emissions Trading Scheme seems likely to have been excessive (partly because the policy regime has been uncertain and because market liquidity still has room to improve, as well as because of the asset-like nature of carbon quotas), considerations like these suggest that careful analysis is required before dismissing the possibility that some response of the carbon price to the business cycle is desirable. This is a particular case of the argument that the discipline of public economics needs both to consider general equilibrium effects of potential policies and to take into account a range of constraints imposed by political economy and market failures, a theme developed further in Stern (2009b).

\section{CONCLUSIONS}

A demand-induced global downturn of the magnitude of the most recent one is a good opportunity to consider how environmental policy should be adjusted by government over the course of the business cycle. In particular, it was argued that, in the most recent downturn, where monetary policy by itself proved inadequate, there was a case for undertaking a step change in the public spending component of environmental policies, focused on socially profitable investment in natural capital. This would need to be accompanied by a strategy for containing the resulting increase in public debt. But countercyclical spending measures need to be evaluated carefully against a number of criteria and not all 'green' initiatives score well as countercyclical tools.

A second conclusion of this paper is that there should be no presumption that the shadow prices associated with environmental problems should be invariant to large macroeconomic shocks. Economic shocks change (and often reduce) the severity of environmental problems and therefore also change (and often reduce) environmental shadow prices. This conclusion holds more strongly for short-term environmental problems (such as congestion) than for long-term problems (such as climate change), where the relevant shadow price is less likely to 
be a function of short-term fluctuations. In any case, while the particular level of the shadow price may adjust, a downturn does not necessarily provide any compelling reason to delay the introduction of price signals to internalise environmental externalities.

A third conclusion is that, given that there is a case for greater public investment in natural capital in an economic downturn, and given that business cycles are difficult to predict, policy makers would be well advised to draw up plans in advance in order to be ready to implement plans rapidly to bolster environmental capital to take advantage of lower opportunity costs when the next downturn occurs.

\section{REFERENCES}

Albrecht, J (2006): 'The use of consumption taxes to re-launch green tax reforms' International Review of Law and Economics, Vol. 26, pages 88-103

Alesina, A, and R Perotti (1995): 'Fiscal expansions and fiscal adjustments in OECD countries' NBER Working Paper No. 5214

Allsopp, C, and D Vines (2005): 'The macroeconomic role of fiscal policy' Oxford Review of Economic Policy, Vol. 21, No. 4, pages 485-508

Andersen, TM (2005): 'Is there a role for an active fiscal stabilization policy?' CESIFO Working Paper 1447, April

Arrow, K, Dasgupta, P, Goulder, L, Daily, G, Ehrlich, P, Heal, G, Levin, S, Mäler, K-G, Schneider, S, Starrett, D, and B Walker (2004): ‘Are we consuming too much?' Journal of Economic Perspectives, Vol. 18, No. 3, pages 147-172

Baldacci, E, Gupta, S and C Mulas-Granados (2009): 'How effective is fiscal policy response in systemic banking crises?' IMF Working Paper 09/160, July

Ball, L, Mankiw, G, and R Reis (2003): 'Monetary policy for inattentive economies' NBER Working Paper 9491

Barro, RJ (1974): 'Are government bonds net wealth?' Journal of Political Economy, Vol. 82, No. 6, pages 1095-1117

Baxter, M, and R King (1993): 'Fiscal policy in general equilibrium' American Economic Review, Vol. 83, No. 3, pages 315-334

Bean, C (2009): The Great Moderation, the Great Panic and the Great Contraction, Schumpeter Lecture, Annual Congress of the European Economic Association, August, available at http://www.bankofengland.co.uk/publications/speeches/2009/speech399.pdf Bhagwati, J (1958): 'Immiserizing Growth: A Geometrical Note' Review of Economic Studies, Vol. 25, pages 201-205

Blanchard, O (2009): Macroeconomics (5th ed.), Upper Saddle River, NJ: Prentice Hall Blanford, G, Richels, R, and T Rutherford (2009):' Feasible climate targets: the roles of economic growth, coalition development and expectations' Energy Economics (2009), Vol. 31, Supplement 2, pages S82-S93

Bovenberg, L, and L Goulder (2002): 'Environmental taxation and regulation' Chapter 23 in the Handbook of Public Economics, Vol. 3, edited by Auerbach, A, and M Feldstein, Elsevier BV, Amsterdam

Bovenberg, L, and F Van der Ploeg (1996): 'Optimal taxation, public goods and environmental policy with involuntary unemployment' Journal of Public Economics, Vol. 62, pages 59-83

Bovenberg, L, and F Van der Ploeg (1998): 'Consequences of environmental tax reform' Environmental and Resource Economics, Vol. 12, pages 137-150 
Bowen, A, Fankhauser, S, Stern, N, and D Zenghelis (2009): 'An outline of the case for a 'green' stimulus' Policy Brief, Grantham Research Institute on Climate Change and the Environment, London School of Economics and Political Science, February

Buiter, W (2008): Fiscal expansion in the wrong places, available at http://blogs.ft.com/maverecon/2008/11/fiscal-expansion-in-the-wrong-places/ Chang, J-J, Chen, J-H, Shieh, J-Y, and C-C Lai (2009): 'Optimal tax policy, market imperfections and environmental externalities in a dynamic optimizing model' Journal of Public Economic Theory, Vol. 11, No. 4, pages 623-651

Christiano, L, Eichenbaum, M, and S Rebelo (2009): 'When is the government spending multiplier large?' manuscript, Northwestern University, August

Dale, S (2009): 'Inflation targeting: learning the lessons from the financial crisis' speech to the Society of Business Economists, June, available at:

http://www.bankofengland.co.uk/publications/speeches/2009/speech395.pdf

Edenhofer, O, and N. Stern (2009): Towards a global green recovery: recommendations for immediate G20 action, report submitted to the G20 London Summit, Potsdam Institute for Climate Impact Research and the Grantham Research Institute on Climate Change and the Environment, April 2009

Fankhauser, S, Sehlleier, F, and N Stern (2008): 'Climate change, innovation and jobs'

Climate Policy, Vol. 8, pages 421-429

Fankhauser, S. and Hepburn, C. (2009): 'Carbon markets in space and time', Vivid

Economics report for UK Department of Energy and Climate Change, May 2009

Feldstein, M (2002): 'The role for discretionary fiscal policy in a low interest rate environment' NBER Working Paper No. 9203

Freedman, C, Kumhof, M, Laxton, D, and J Lee (2009): 'The case for global fiscal stimulus' IMF Staff Position Note 09/03, March

Geman, H (2005): Commodities and commodity derivatives, John Wiley and Sons Ltd, Chichester

Giavazzi, F, and M Pagano (1990): 'Can severe fiscal contractions be expansionary? Tales of two small European countries' CEPR Discussion Paper 417

Hemming, R, Kell, M, and S Mahfouz (2002): 'The effectiveness of fiscal policy in stimulating economic activity - a review of the literature' IMF Working Paper 02/208, December

Hemming, R, Mahfouz, S, and A Schimmelpfennig (2002): 'Fiscal policy and economic activity during recessions in advanced economies' IMF Working Paper 02/87, May Houser, T, Mohan S, and R Heilmayr (2009): 'A green global recovery? Assessing US economic stimulus and the prospects for international coordination' Peterson Institute for International Economics and World Resources Institute Policy Brief 09/3

HSBC (2009): 'A global green recovery? Yes, but in 2010', HSBC Global Research, August IEA (2008): World Energy Outlook 2008, International Energy Agency, Paris

IFS (2008): Pre-Budget Report, Institute for Fiscal Studies, November, available at http://www.ifs.org.uk/publications.php?publication_id=4363

IMF World Economic Outlook, various issues

IMF (2009a): 'Global economic policies and prospects', a note by the staff of the International Monetary Fund for the Group of Twenty meeting, March 13-14, 2009 IMF (2009b): World Economic Outlook, April

Kaminskaite-Salters, G, et al (2009): Meeting the climate challenge: using public funds to leverage private investment in developing countries, Grantham Research Centre for Climate Change and the Environment, London School of Economics and Political Science, London, September 
Kammen, DM, Kapadia, K, and M Fripp (2006): Putting renewables to work: how many jobs can the clean energy industry generate? Report of the Renewable and Appropriate Energy Laboratory, University of California, Berkeley, April 2004 (corrected January 2006)

Kristom, B, and P Riera (1996): 'Is the income elasticity of environmental improvements less than one?' Environmental and Resource Economics, Vol. 7, pages 45-55

Krugman, P (2005): 'Is fiscal policy poised for a comeback?' Oxford Review of Economic Policy, Vol. 21, No. 4, pages 515-523

Lane, P (2003): 'The cyclical behaviour of fiscal policy: evidence from the OECD' Journal of Public Economics, Vol. 87, pages 2661-2675

Leith, C, and S Wren-Lewis (2005): 'Fiscal stabilization policy and fiscal institutions' Oxford Review of Economic Policy, Vol. 21, No. 4, pages 584-597

Lucas, R (1987): Models of the business cycle, Basil Blackwell, Oxford

Mäler, K-G, and M Munasinghe (1996): 'Macroeconomic policies, second-best theory and the environment' Environment and Development Economics, Vol. 1, pages 149-163

Mansanet-Bataller, M, Pardo, A, and E Valor (2007): ' $\mathrm{CO}_{2}$ prices, energy and weather' The Energy Journal, Vol. 28, No. 3, pages 67-86

McKinsey\&Company (2009): Pathways to a low-carbon economy, January

Metcalf, G (2009): 'Cost containment in climate change policy: alternative approaches to mitigating price volatility' NBER Working Paper No. 15125, July

Munasinghe, M (1999): 'Is environmental degradation an inevitable consequence of economic growth: tunneling through the environmental Kuznets curve' Ecological Economics, Vol. 29, pages 89-109

Neumayer, E (2003): Weak versus strong sustainability, Edward Elgar, Cheltenham, UK Neumayer, E (2007): 'A missed opportunity: the Stern Review on climate change fails to tackle the issue of non-substitutable loss of natural capital' Global Environmental Change, Vol. 17, pages 297-301

New Energy Finance (2009): Clean energy investment in the economic downturn, Paper submitted to the GLOBE G8+5 legislators' meeting, Rome, June

Newell, R and W Pizer (2003): 'Regulating stock externalities under uncertainty', Journal of Environmental Economics and Management, Vol. 45, pages 416-432

OECD (2008): Environmental Outlook, OECD, Paris

Pigou, A (1932): The Economics of Welfare, 4th edition, MacMillan, London

Pizer, WA (2002): 'Combining price and quantity controls to mitigate global climate change' Journal of Public Economics, Vol. 85(3), pages 409-434, September

Pollins, R, Garrett-Peltier, H, Heintz, J, and H Scharber (2008): Green recovery: a program to create good jobs and start building a low-carbon economy, PERI and the Center for

American Progress, September

Pollins, R, Heintz, J, and H Garrett-Peltier (2009): The economic benefits of investing in clean energy, PERI and the Center for American Progress, June

Ricciuti, R (2003): 'Assessing Ricardian equivalence' Journal of Economic Surveys, Vol. 17, pages $55-78$

Roland-Holst, D (2008): Energy efficiency, innovation, and job creation in California, Center for Energy, Resources, and Economic Sustainability, University of California, Berkeley, October

Sarantis, N, and C Stewart (2003): 'Liquidity constraints, precautionary saving and aggregate consumption: an international comparison' Economic Modelling, Vol. 20, pages 1151-1173 Sinn, H-W (2008): 'Public policies against global warming: a supply-side approach' International Tax and Public Finance, Vol. 15, pages 360-394

Spilimbergo, A, Symansky, S, Blanchard, O, and C Cottarelli (2008): 'Fiscal policy for the crisis' IMF Staff Position Note SPN/08/01, Washington DC 
Stern, D (2003): The environmental Kuznets curve, Internet Encyclopaedia of Ecological Economics

Stern, N (2007): The economics of climate change, Cambridge University Press, Cambridge Stern, N (2008a): 'The economics of climate change' American Economic Review, Vol 98, No 2, pages 1-37

Stern, N (2008b): Key elements of a global deal on climate change, London School of Economics and Political Science, London

Stern, N (2009a): A Blueprint for a Safer Planet, The Bodley Head, London

Stern, N (2009b): Imperfections in the economics of public policy, imperfections in markets, and climate change, Presidential Lecture for the European Economic Association, Barcelona, August

Sutherland, A (1997): 'Fiscal crises and aggregate demand: can high public debt reverse the effects of fiscal policy?' Journal of Public Economics, Vol. 65, pages 147-162

Taylor, JB (2000): 'Reassessing discretionary fiscal policy' Journal of Economic

Perspectives, Vol. 14, pages 21-36

Taylor, JB (2009): 'The lack of an empirical rationale for a revival of discretionary fiscal policy' American Economic Review: Papers and Proceedings, Vol. 99, No.2, pages 550-555 Tietenberg, T, and L Lewis (2008): Environmental and Resource Economics, ${ }^{\text {th }}$ Edition, Prentice Hall, Inc., Upper Saddle River, New Jersey

UN (2008): The Millennium Development Goals Report, The United Nations, New York UNEP (2009a): UNEP Annual Report 2008, United Nations Environment Programme, Nairobi

UNEP (2009b): Catalysing low-carbon growth in developing countries, Report by Vivid Economics for United Nations Environment Programme Finance Initiative and Partners. UNFCCC (2007): Investment and financial flows to address climate change, United Nations Convention on Climate Change, Bonn

Wade, J, Wiltshire, V, and I Scase (2000): National and local employment impacts of energy efficiency investment programmes, Vol. 1 (Summary Report), April, Association for the Conservation of Energy, London

Webster, M, Paltsev, S, Parsons, J, Reilly, J, and H Jacoby (2008): 'Uncertainty in greenhouse emissions and costs of atmospheric stabilization' Joint Program Report Series No. 165, MIT Joint Program on the Science and Policy of Global Change, November

TABLE 1

IMF Global Growth Projections for 2009 (Real GDP \%)

\begin{tabular}{|c|c|c|c|c|c|c|c|c|}
\hline Region/country & $\begin{array}{c}\text { Apr } \\
2008 \\
\end{array}$ & $\begin{array}{l}\text { Jul* } \\
\text { 2008 } \\
\end{array}$ & $\begin{array}{c}\text { Oct } \\
2008\end{array}$ & $\begin{array}{l}\text { Nov* } \\
2008 \\
\end{array}$ & $\begin{array}{l}\text { Jan* } \\
2009\end{array}$ & $\begin{array}{c}\text { Apr } \\
2009 \\
\end{array}$ & $\begin{array}{l}\text { Jul* } \\
2009 \\
\end{array}$ & $\begin{array}{c}\text { Oct } \\
2009 \\
\end{array}$ \\
\hline World & 3.8 & 3.9 & 3.0 & 2.2 & 0.5 & -1.3 & -1.4 & -1.1 \\
\hline $\begin{array}{l}\text { Advanced } \\
\text { economies }\end{array}$ & 1.3 & 1.4 & 0.5 & -0.3 & -2.0 & -3.8 & -3.8 & -3.4 \\
\hline Euro area & 1.2 & 1.2 & 0.2 & -0.5 & -2.0 & -4.2 & -4.8 & -4.2 \\
\hline US & 0.6 & 0.8 & 0.1 & -0.7 & -1.6 & -2.8 & -2.6 & -2.7 \\
\hline UK & 1.6 & 1.7 & -0.1 & -1.3 & -2.8 & -4.1 & -4.2 & -4.4 \\
\hline $\begin{array}{l}\text { Developing } \\
\text { economies }\end{array}$ & 6.6 & 6.7 & 6.1 & 5.1 & 3.3 & 1.6 & 1.5 & 1.7 \\
\hline China & 9.5 & 9.8 & 9.3 & 8.5 & 6.7 & 6.5 & 7.5 & 8.5 \\
\hline
\end{tabular}

*WEO Update report 
Source: IMF WEO.

IMF Global Growth Projections for 2002 (Real GDP \%)

\begin{tabular}{lccccc}
\hline Region/country & $\begin{array}{c}\text { May } \\
2001\end{array}$ & $\begin{array}{c}\text { October } \\
2001\end{array}$ & $\begin{array}{c}\text { December } \\
2001\end{array}$ & $\begin{array}{c}\text { April } \\
2002\end{array}$ & $\begin{array}{c}\text { September } \\
2002\end{array}$ \\
\hline World & 3.9 & 3.5 & 2.4 & 2.8 & 2.8 \\
Advanced economies & 2.7 & 2.1 & 0.8 & 1.7 & 1.7 \\
Euro area & 2.8 & 2.2 & 1.2 & 1.4 & 0.9 \\
US & 2.5 & 2.2 & 0.7 & 2.3 & 2.2 \\
UK & 2.8 & 2.4 & 1.8 & 2.0 & 1.7 \\
Developing economies & 5.6 & 5.3 & 4.4 & 4.3 & 4.2 \\
China & 7.1 & 7.1 & 6.8 & 7.0 & 7.5 \\
\hline
\end{tabular}

Source: IMF WEO.

IMF Global Growth Projections for 2010 (Real GDP \%)

\begin{tabular}{lcccc}
\hline Region/country & Jan* & Apr & Jul* & Oct \\
& 2009 & 2009 & 2009 & 2009 \\
\hline World & 3.0 & 1.9 & 2.5 & 3.1 \\
Advanced economies & 1.1 & 0.0 & 0.6 & 1.3 \\
Euro area & 0.2 & -0.4 & -0.3 & 0.3 \\
US & 1.6 & 0.0 & 0.8 & 1.5 \\
UK & 0.2 & -0.4 & 0.2 & 0.9 \\
Developing economies & 5.0 & 4.0 & 4.7 & 5.1 \\
China & 8.0 & 7.5 & 8.5 & 9.0 \\
\hline
\end{tabular}

*WEO Update report

Source: IMF WEO. 


\section{CHART 1: Effects of global fiscal stimulus with monetary accommodation}

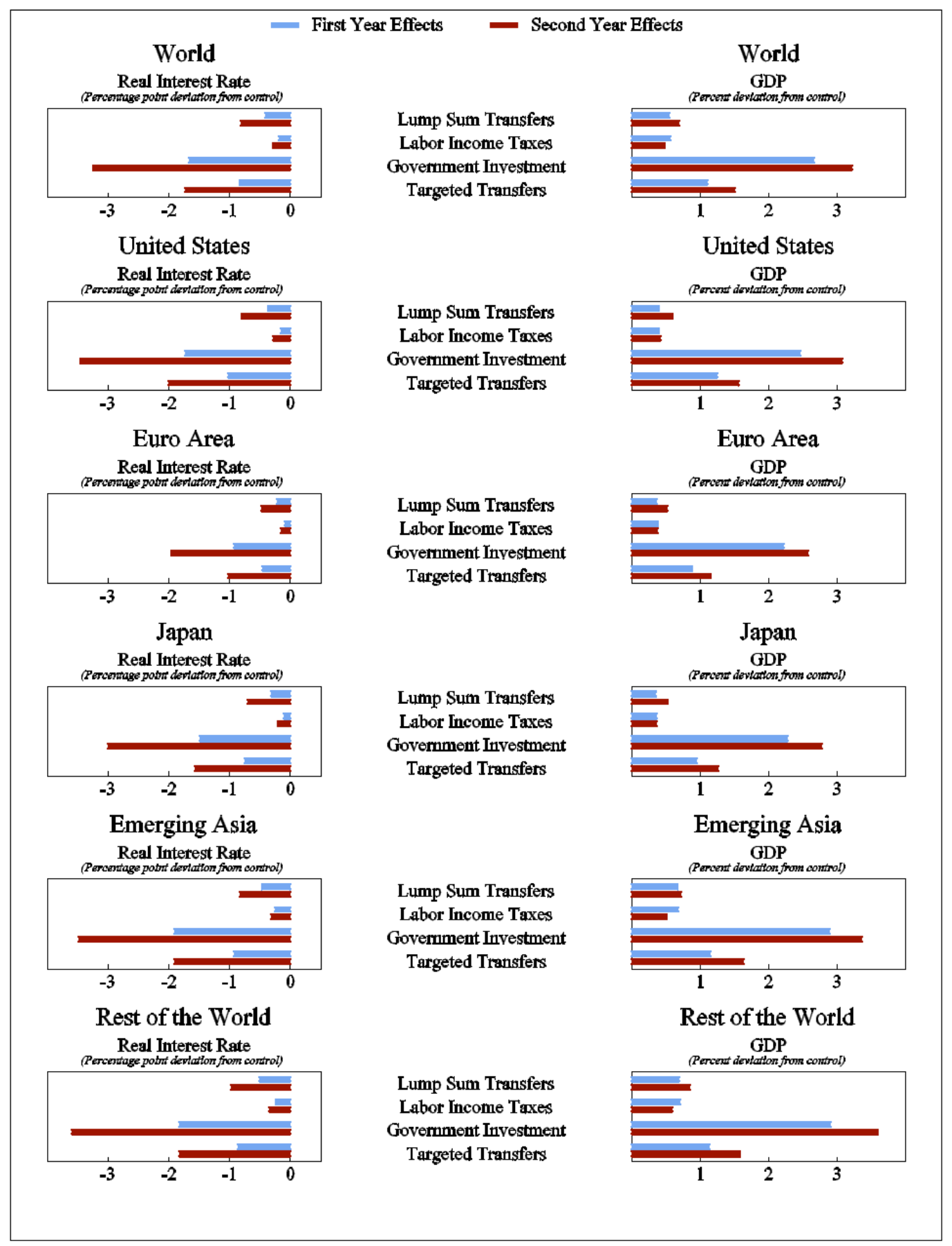

Note: simulations assume that all countries implement a fiscal expansion of $1 \%$ of GDP in year (1) and $0.5 \%$ of GDP in year (2), with policy interest rates held constant and lump-sum transfers used to offset changes in budgets due to automatic stabilisers.

Source: Freedman et al (2009) 
TABLE 2

\begin{tabular}{|l|l|l|l|l|l|l|l|l|}
\hline $\begin{array}{l}\text { Region/ } \\
\text { country }\end{array}$ & \multicolumn{3}{l}{$\begin{array}{l}\text { Overall fiscal balance } \\
\text { \% GDP) }\end{array}$} & $\begin{array}{l}\text { Average annual change in 2008-10 from level in } \\
\text { 2007 (\% points of GDP) }\end{array}$ \\
\hline & 2007 & 2008 & 2009 & 2010 & $\begin{array}{l}\text { Overall } \\
\text { balance }\end{array}$ & $\begin{array}{l}\text { Automatic } \\
\text { stabilisers }\end{array}$ & $\begin{array}{l}\text { Discretionary } \\
\text { measures }\end{array}$ & Other \\
\hline G20 & -1.1 & -2.6 & -5.9 & -6.3 & -3.8 & -1.4 & -1.2 & -1.2 \\
\hline EU G20 & -1.6 & -2.7 & -6.0 & -6.9 & -3.5 & -2.2 & -0.6 & -0.7 \\
\hline China & 0.9 & -0.3 & -3.6 & -3.6 & -3.4 & -0.6 & -2.1 & -0.7 \\
\hline USA & -2.9 & -5.9 & -7.7 & -8.9 & -4.6 & -1.6 & -1.6 & -1.4 \\
\hline UK & -2.7 & -5.5 & -9.5 & -11.0 & -6.0 & -2.5 & -0.5 & -2.9 \\
\hline
\end{tabular}

Source: IMF (2009a), Table 3

TABLE 3

\begin{tabular}{lllll}
\hline Region/country & $\begin{array}{l}\text { Total } \\
\text { stimulus } \\
\text { (USDbn) }\end{array}$ & $\begin{array}{l}\text { Period } \\
\text { (years) }\end{array}$ & $\begin{array}{l}\text { 'Green' } \\
\text { stimulus } \\
\text { (USDbn) }\end{array}$ & $\begin{array}{l}\text { 'Green' } \\
\text { stimulus } \\
(\%)\end{array}$ \\
\hline China & 649.1 & $2009-2010$ & 218.0 & 33.6 \\
Japan & 639.9 & $2009-$ & 36.0 & 5.6 \\
South Korea & 76.1 & $2009-2012$ & 59.9 & 78.8 \\
Sub-total Asia Pacific & $1,558.5$ & & 334.1 & 21.4 \\
United Kingdom & 34.9 & $2009-2011$ & 5.2 & 10.6 \\
Sub-total EU & 537 & & 55.2 & 10.3 \\
US & 976.9 & 10 years & 117.2 & 12.0 \\
Sub-total Americas & $1,024.1$ & & 121.2 & 11.8 \\
Grand total & 3,130 & & 512 & 16.4 \\
\hline
\end{tabular}

Source: HSBC (2009) 